\title{
ANTITRUST POLICY: A PROBLEM IN STATECRAFT
}

\author{
BY KENNETH S. CARLSTON $†$
}

IT is a unique phenomenom of our American democracy that it has largely turned over to the courts the task of determining when business institutions are acting in the public interest. The Sherman Act of 1890 condemned restraints of trade and monopolizing in commerce and the cryptic phrases of the statute were left to the courts for interpretation. In practically no other country of the world have lawyers and judges been delegated with "the essentially political, economic and social function of deciding when business men are acting reasonably and when they are not."1

Few in 1890 and few since 1890 have questioned the wisdom of this step. Complaints have been many as to the manner in which the courts were carrying out their task. But there has been substantial acceptance of the thesis that legal control of the business institution is essential. It is the purpose of this article to examine the implications of that thesis and to suggest certain ways in which that control can be more effectively accomplished in the public interest.

\section{Antitrust Law and the Distributron of Power in the Community}

Until the nineteenth century the problem of the possession of power in the community was primarily a political one. The modern nation-state had emerged from the feudalism of the Middle Ages possessed with absolute political power or sovereignty. The feudal system had been subject to the restraints of the code of chivalry, the system of mutual obligations of fealty and protection between man and lord, and the authority of the Church. The king for a time, particularly in England, was conceived to be subject to the restraint of the fundamental principles of natural law, though otherwise possessed, in the words of Bodin, of summa potestas or supreme power. But following Hobbes the sovereign command, resting in the possession of absolute might and power, became law uncontrolled by any fundamental principles of justice. The protection of the individual from the exertion of uncontrolled and absolute power was accordingly seen to be a problem involving the limitation of the power of the state in matters of vital concern to the security and integrity of the individual. Hence the American Declaration of Independence in 1776, the French Declaration of the Rights of Man adopted by the revolutionary National Assembly of France in 1789 and the Bill of Rights annexed to our own Federal Constitution declared the rights of man as against the power of the state.

$\dagger$ Professor of Law, University of Illinois.

1. Whitney, The Trial of an Anti-Trust Case, 5 The Record of the Assoctation or the Bar of the City of New York, 449, 457 (1950). 
The industrialization of the United States in the nineteenth century, however, posed a new problem in power for the commonwealth to solve. Though industrialization had grown rapidly, the United States was still predominantly an agricultural nation prior to the Civil War. Our principal imports were manufactures and our principal exports were agricultural products. The corporate enterprise was an important part of the national scene but its possession of power had not yet become a national problem. Its status under the law was that of an autonomous institution ${ }^{2}$ essentially free from any legal controls other than those applicable to any private person. It was required to keep its promises, to make good its torts and to obey the criminal law. Of vastly greater importance, however, was, the fact that, through the fiction of corporate personality and resultant identification of the corporation with the individual, the corporation possessed the right of contract and the right to property. Liberty of contract assured it freedom to pursue its ends and enabled it to bring all the power of the state to bear in maintaining the relationships thus established with others. The right to property assured it freedom and power to control whatever capital equipment it might find necessary to achieve its purposes. The exercise of these powers was subject only to the limitation that they should not be used in unlawful or criminal enterprises; efforts to control their exercise short of this point were struck down as an impairment of contract. The possession of these powers in all their freedom posed no particular problem for the body politic in the first half of the nineteenth century. Corporate groups were not then the repositories of economic power that they later became when their autonomy from the state, coupled with their endowment of legal authority by the state under the con-

2. The reader is cautioned that the term "institution" is not herein used in the sense of "a cluster of social usages" 8 ENCYC. Soc. Sciences, 84 (1932) but rather in the sense of a system of relationships established among individuals towards achieving certain desired ends. More particularly, it comprises a group of individuals in close cooperative, reciprocating relationship with one another, (1) characterized, i.e., separated from other groups, by the distinctively purposeful character of its activity, (2) possessing relative permanence derived from the significance of those participating in the group and affected by it of the ultimate purpose which it is seeking in its activity to achieve, (3) possessing an internal structure characterized by (a) a directing personnel (i) coordinating and directing the activity of the group, which will be separated from the other members of the group with varying degrees of preciseness, depending upon the complexity of development and size of the group, and (ii) safeguarding the continuance of the group as against the aggressions of other groups, including the establishment and maintenance of bases of interaction with such groups, (b) means of communication within the group, and (c) internal norms of conduct and sanctions therefor designed to induce conformity to such norms and to prevent or punish departures therefrom, and (4) controlling certain definite apparatus employed by the group in achieving and expressing its idea. When the facade of corporate personality is thus ignored and the fact realized that the corporate group is essentially a system of relationships, the concern of the legal process in the control of the corporate institution becomes very much simplified. The function of law in such circumstances becomes one of preserving and buttressing those relationships in the corporate institution, whether internal to the institution or external, which are socially desirable and inhibiting those which are not. 
cepts of freedom of contract and right of property, made unregulated corporate decisions a new problem in power. For the corporate groups of the latter nineteenth century were vastly greater and more complex in their structure than those of the early nineteenth century. The pace of industrialization after the Civil War in itself posed difficult problems of social adjustment, including all the problems incident to rapid urbanization, overcrowding, slums, and the subjection of the individual to the massive, impersonal currents of an industrial civilization. Of greater significance was the fact that there were new giants in the land, combinations, trusts, monopolies and great corporate enterprises.

Legislative efforts to control these giants had to run the gantlet of judicial review under the invigorated concept of due process. The concentration of the vast new wealth into the hands of these new giants posed in a new form the problem of power which the preceding century had solved through the bill of rights and a federal government of checks and balances. Both the major political parties in the campaign of 1888 proposed the regulation of combinations and trusts in an effort to capture the vote of those who had denounced the concentration of capital. The Sherman Act of 1890 was the final outcome of the struggle of the nineteenth century to bring the new and vast repositories of economic power under the control of law. Not regulation but abolition was its philosophy. Contracts and combinations in restraint of trade and monopolizing were made not only unlawful, they were made criminal. The money changers were to be cast from the temple and the common man was thus to find protection against those whom a later president of the United States termed "malefactors of great wealth."

It was true that the hoped-for elimination of restraints of trade and of monopolies condemned by the act would, if accomplished, bring to this most imperfect of worlds self-regulatory competition in all its virtue and perfection. But the public issue in the enactment of the Sherman Act was not solely or even primarily an economic one. It was one outcome of a vast transformation of society. No longer did the American frontier exist where man could find refuge from the vicissitudes of an industrial civilization. No longer did the self-sustaining farm provide a measure of security for the majority of the citizenry. Men were city dwellers. They were caught by the factory, caught by the office building. They were helpless units, each exercising his particular function in the corporate enterprise and each bargaining alone against that enterprise, whether as employee or consumer. In short, man sought a new bill of rights in the nineteenth century and found it in the promised abolition of trusts and combinations.

Twenty-one years later in the Standard Oil case ${ }^{3}$ the judicial interpretation of the act became of age. Where previously all contracts in restraint of trade fell under the condemnation of the act, ${ }^{4}$ now the door became open

3. Standard Oil Co. of New Jersey v. United States, 221 U.S. 1 (1911).

4. United States v. Trans-Missouri Freight Ass'n, 166 U.S. 290, 331-2 (1897). 
through the general concept of reasonableness to the recognition of a variety of values. In place of rigorous inflexibility, flexibility and possibility of compromise were introduced. The spotlight of judicial interpretation shifted from the words of the statute to the realities of economic life, in which there is no ultimate truth, no best of all possible worlds, but only a balancing of interests and objectives. No longer was the basic concept abolition but, instead, regulation.

Two decades more and a new problem of control of economic power arose. The problem of the nineteenth century involved, as we have seen, a relationship between the individual and the great corporate institution endowed with the powers of contract and property and the freedom to exercise these solely in the corporate interest under the constitutional protections of liberty of contract and due process. The vulnerability of the individual in this relation resulted in the political demand that found its expression in the Sherman Act. The American culture, a product of the frontier, resisted centralization of authority whether found in the political institution or in the economic. But the world-wide depression of the thirties focused a new attitude toward law. The power implicit in law no longer was per se an evil. Law, in the view of Jhering and the body politic of the twentieth century, was a means to an end. The sensitive, complex organization of modern industrial society, the failure of an unregulated competitive system to minimize the vicissitudes of the business cycle, the external stresses of war and threat of war, demanded a powerful centralized government. Hence an increasingly active intervention by the modern state in the functioning of the competitive system. The state assumed the role of the service state, supplanting or supporting, as the case may be, the private corporate enterprise. ${ }^{5}$ This development carried logically to its end brought into being the totalitarian state, which could brook no rivals to its possession of power. The corporation either became the servant of the state in the execution of its policies, as in Nazi Germany, or it became a vehicle and agency of the state itself, as in Communist Russia. ${ }^{6}$

In this country, however, as the state has shifted from a protective to an increasingly directive role and has gained in power, we have seen the use of antitrust prosecutions as political weapons. A sudden spurt of inflation and the causing factors are proclaimed by the government to be "monopolists" rather than governmental policies. Antitrust suits against commodity speculators are threatened or filed to find a scapegoat for public wrath. This is not to say that the traditional historical objective has diminished. It is only to suggest that a new issue may be in the process of being added, that of a power relationship between the corporate group itself and the state.

5. Pound, Law in the Service State: Freedom versus Equality, 36 A.B.A.J. 977 (1950).

6. 1 Gsovski, The Law of the Soviet State 639 (1948); Hazard, Socialism, Abuse of Power, and Soviet Law, 50 CoL. L. Rev. 448, 449 (1950). 


\section{Antitrust Law and the Judictal Process}

In the Standard Oil decision the courts assumed a task impossible for them satisfactorily to discharge. It may well be that the decision in that case to face economic realities, to move from the domain of statutory interpretation into the domain of the functioning of the economic system, had even then been too long deferred. It may also well be that there is no equally satisfactory alternative means of control of the activity of the business institution than under the Sherman Act so construed. Once, however, the courts admitted to judicial inquiry the question of the reasonableness of the activities of business institutions, they moved into a realm where economists even today tread lightly and with an unsure foot. For, as Justice Peckham pointed out in 1897, ${ }^{7}$ issues of reasonableness in the economic sphere are extremely difficult to handle from the standpoint of judicial administration. Law is fundamentally concerned with norms for conduct. Criminal law in particular is concerned with definite, objective norms the violation of which entails penalty. (And it must be remembered in this connection that there are no degrees of turpitude involved in violations of the Sherman Act; it is a matter of indifference under the law if a violation exists whether it is to be subjected to the civil or the criminal procedures of the statute.) The judicial process proceeds case by case, precedent by precedent, to build up rules or norms of general application. These are to be applied in subsequent similar cases in all the inexorability and majesty of established principles of law. But objective standards of reasonableness are at best, even in relatively simple fact situations, difficult to establish in advance. Circumstances vary from case to case and what is reasonable in the circumstances varies from case to case. When the issue is what restraints are reasonable in a situation involving business conduct or the structure of business organization, rarely will the precise questions of fact be similar and usually they will be quite complex.

To illustrate, in a particularly flagrant case of a price-fixing agreement in the Trenton Potteries case, ${ }^{8}$ the Supreme Court laid down the rule that such an agreement "by those controlling in any substantial manner a trade or a business in interstate commerce" was illegal per se. The certainty of the rule thus laid down proved illusory in the subsequent Appalachian Coal case, ${ }^{0}$ only to be restored again to favor in the Socony- $V$ acuum case. ${ }^{10}$

The administrative factor in the judicial process, the search for rules of general application which will relieve the court of the trial burdens incident to a case-by-case approach and will provide business institutions with definite rules of guidance, had a curious application from the standpoint of the economist in the Standard of California decision. In a series of decisions beginning

7. United States v. Trans-Missouri Freight Ass'n, 166 U.S. 290 (1897).

8. United States v. Trenton Potteries Co., 273 U.S. 392, 398 (1927).

9. Appalachian Coals, Inc. v. United States, 288 U.S. 344 (1933).

10. United States v. Socony-Vacuum Oil Co., 310 U.S. 150 (1940). 
with the Dry Ice case ${ }^{11}$ the court had laid down the rule that it was illegal to extend the lawful monopoly of a patent to control any unpatented materials used in connection with the patent. This was reaffirmed recently in the International Salt case, when the court took occasion to say: "It is unreasonable, per se, to foreclose competitors from any substantial market."12 In the subsequent Standard of California case these words were seized upon in a proceeding under Section 3 of the Clayton Act, which prohibited tying clauses, to limit the judicial inquiry into the question of the reasonableness of requirements contracts between a petroleum supplier and gasoline dealers to the sole issue whether such contracts involved "a substantial share of the line of commerce affected."13 It may parenthetically be noted that the troublesome problem of determining when a substantial injury to competition had occurred had in the meantime also become simplified from the administrative standpoint by the substitution of "reasonable possibility"14 for "reasonable probability." Considerations as to the economic advantages of requirements contracts not negotiated under the duress of a patent monopoly or as to whether Standard of California had a dominant position in the market concerned (only $6.7 \%$ of the total market in the area was affected by the contracts in question) accordingly became irrelevant and the judicial task enormously simplified. Evidence as to the effects on competition of the practice attacked was, in the view of Justice Frankfurter, "most ill-suited for ascertainment by courts."16 In commenting on the practical effect of this decision one of our most acute attorneys in the Antitrust Division recently made the following remarks, which may occasion some surprise to the economist or businessman:

"In restricting the court's economic scrutiny to the single criterion of substantiality of industrial coverage, the case eliminates the need for canvassing the complex economic considerations usually advanced as supporting the reasonableness of exclusive distributorships. Thus, the courts need no longer ponder or evaluate allegations that competition in the industry had not in fact been adversely affected; that costs to the seller or buyer have been reduced; that the buyer is assured of his supply and protected against price increases; that the seller does not dominate the industry. These are issues which tend to inflate, rather than to illuminate, this kind of antitrust record, and

11. Carbice Corp. v. American Patents Development Corp., 283 U.S. 27 (1931).

12. International Salt Co. v. United States, 332 U.S. 392, 396 (1947).

13. Standard Oil Co. of Calif. v. United States, 337 U.S. 293, 314 (1949). The complaint also alleged a violation of Section 1 of the Sherman Act but the court found it unnecessary to rule on this point in view of the finding of a violation of Section 3 of the Clayton Act.

14. FTC v. Morton Salt Co., 334 U.S. 37, 46 (1948).

15. Corn Products Refining Co. v. FTC, 324 U.S. 726, 739 (1945).

16. Standard Oil Co. of Calif. v. United States, 337 U.S. 293, 310 (1949). 
the best way to economize an antitrust proceeding is still the obvious one of cutting down the number of issues in dispute." 17

The tendency of the legal mind to classify essentially dissimilar fact situations into the same legal pigeonhole, evidenced in the above discussion concerning the application of a rule of law growing out of a particular abuse of patent rights to a situation involving the use by a business enterprise of requirements contracts as a means of achieving a loose vertical integration into a retail market, may come something as a surprise to the mind of the economist. In each, the incident of the exclusion of competing suppliers from the segment of the market affected by the questioned action is made a turning point for the decision. In the first case, the incident is viewed in its context but in the second it is viewed isolated from its context. Whether from the standpoint of economics or public policy a sound result is reached in the second case is accordingly a matter of chance. All such considerations are excluded as "ill-suited for ascertainment by courts."

In the Yellow $C a b$ case ${ }^{18}$ the court was confronted with the incident of exclusion of competing suppliers from an appreciable segment of the market, this time also in a context of vertical integration of a business institution. A manufacturer of taxicabs had found the answer to its sales manager's prayer by buying into control of local monopolies of the taxicab business. To bring customers for taxicabs thus shielded from competition into the corporate fold of the manufacturer was to assure an impregnable outlet for a considerable volume of sales of taxicabs. The court held that a complaint under Sections 1 and 2 of the Sherman Act stated a prima facie case of a conspiracy "to monopolize or restrain . . . an appreciable segment of interstate cab sales."19 In other words, the case turned not on the questionable economic soundness of a vertical integration of this character (query as to its soundness from the profit standpoint) but on the loss of sales by competing taxicab manufacturers as the result of the integration.

Whether and in what circumstances the law should show solicitude for competitors thus excluded by a vertical integration was directly posed in the Standard of California case just discussed but, inasmuch as that case was disposed of on the basis of Section 3 of the Clayton Act, the prior Yellow $C a b$ case arising solely under the Sherman Act became irrelevant. Consequently not until the Columbia Steel case ${ }^{20}$ was this issue again directly presented to the courts. Here the issue was faced in the context of a vertical corporate integration by United States Steel with Consolidated Steel into the fabricated steel market in the western states. A market analysis of the

17. Timberg, The Rights of Cistomer-Seller Selection, CCH Federal Antrraust Law Symposium, 151, 153-4 (1951).

18. United States v. Yellow Cab Co., 332 U.S. 218 (1947).

19. Id. at 226 .

20. United States v. Columbia Steel Co., 334 U.S. 495 (1948). 
relative position of the two concerns in their respective fields was made, and the decision reached that the integration was valid notwithstanding the consequent loss to competing suppliers of the segment of the market represented by Consolidated's purchases. The Yellow Cab case was considered and found not to support the conclusion that "all exclusive dealing arrangements are illegal per se."21 Yet at the succeeding term of the court it came close indeed to that very conclusion in the Standard of California case. And in the recent National City Lines case, ${ }^{22}$ involving exclusive dealing arrangements between transit equipment suppliers and bus transportation companies, the $Y$ ellow $C a b$ situation was again presented to the lower courts and the $Y$ ellow $C a b$ rule again applied against the suppliers there defendants. Finally, after trial of the Yellow $C a b$ case itself upon remand from the Supreme Court, judgment for the taxicab manufacturer was sustained in the Supreme Court in view of the ruling of the trial judge that the integration was due not to an illegal intent to restrain trade but to "other business factors."23

The problem of joint activities of business institutions tending to affect the free determination of prices in the market has been viewed, as we saw at the outset of this section, in the common law tradition that any such tampering with the market is per se an evil. Occasionally, as in the Appalachian Coal case and the earlier Chicago Board of Trade case, ${ }^{24}$ other aspects of the basic economic problems involved break through and demand judicial scrutiny. Usually, however, the force of this line of precedent and authority confines the judicial investigation to the sole question whether there has been concerted action by competitors. Thus in the American Column \& Lumber case ${ }^{25}$ the formal legal issue was whether some 400 manufacturers of hardwood producing about one-third of the total United States production could disseminate price information among one another through a trade association. The Court held this to be "abnormal conduct" involving undue cooperation among the competitors. Justice Brandeis in a dissent called attention to the basic economic consequences of the decision:

"The refusal to permit a multitude of small rivals to cooperate, as they have done here, in order to protect themselves and the public from the chaos and havoc wrought in their trade by ignorance, may result in suppressing competition in the hardwood industry. These keen business rivals, who sought through cooperative exchange of trade information to create conditions under which alone rational competition is possible, produce in the aggregate about one-third of the hardwood lumber of the country. This court held in United States v. United States Steel Corporation, 251 U.S. 417, that it was not unlawful to vest in a single

21. Id. at 523.

22. United States v. National City Lines, 186 F.2d 562 (7th Cir. 1951).

23. United States v. Yellow Cab Co., 338 U.S. 338 (1949).

24. Board of Trade of the City of Chicago v. United States, 246 U.S. 231 (1918).

25. American Column \& Lumber Co. v. United States, 257 U.S. 377 (1921). 
corporation control of 50 per cent. of the steel industry of the country; and in United States v. United Shoe Machinery Co., 247 U.S. 32, the court held that it was not unlawful to vest in a single corporation control of practically the whole shoe machinery industry. May not these hardwood lumber concerns, frustrated in their efforts to rationalize competition, be led to enter the inviting field of consolidation? And if they do, may not another huge trust with highly centralized control over vast resources, natural, manufacturing and financial, become so powerful as to dominate competitors, wholesalers, retailers, consumers, employees and, in large measure, the community?'"26

With the doors thus closed to trade association activities as a weapon of small business against their giant competitors, the inevitable economic consequences of the decision were, first, an additional stimulus towards bigness (i.e., the integrated single business unit) as prophesied by Brandeis, and, second, a strengthening of the reaction by small business against bigness itself which is now evident.

The public acceptance of the antitrust laws and faith in the rationality and justice of the judicial process has enabled the courts to enter upon highly controversial domains of public policy which are closed to the more open legislative process. Legislation is always a compromise among conflicting interests and sometimes that compromise can only be achieved through elusive language. In other words, the courts may perhaps more easily rush in where the legislature fears to tread. The problem of the chain store can be dealt with legislatively by a Robinson-Patman Act but not the dissolution of the A \& P grocery chain itself. A more apt illustration may be found in the history of the public control of basing-point practices. In condemning under Section 2 of the Clayton Act a basing-point system adopted by Corn Products Refining Company, the court acknowledged that Congress in enacting the Robinson-Patman amendment to this section did not intend to prohibit multiple basing-point systems. ${ }^{27}$ Yet, on the authority of Section 2 of the Clayton Act, as amended by the Robinson-Patman Act, and Section 5 of the Federal Trade Commission Act, the court three years later condemned a multiple basing-point system..$^{28}$ Efforts by Congress to clarify the legal status of basing-point practices presented by the last decision resulted in bitter debate, a compromise bill that was worded with considerable vagueness, and a presidential veto.

The foregoing analysis is believed to furnish at least some persuasive support for the conclusion that the mind and training of the lawyer do not necessarily approach the solution of the problem of what business activities are in the public interest in the same manner as the mind and training of the economist.

26. Id. at 418-19.

27. Corn Products Refining Co. v. FTC, 324 U.S. 726, 737 (1945).

28. FTC v. Cement Institute, 333 U.S. 683 (1948). 
The lawyer seeks as a basis for decision analogous precedents in which the analogous element unifying the precedent with the situation at hand may well be derived from wholly dissimilar contexts. The precedent then becomes the rule for decision. Whether the basic economic problems are grappled with in any one case accordingly tends to be fortuitous. Always the approach of the advocate is to cite cases and to try to bring the new case within established precedents and rules of law. All the artifices of logic and semantics are utilized to this end. The courts are "ill-suited" to weigh and evaluate economic criteria; even when such criteria are considered by the courts, it is always within the framework of issues of previously established case-law. This reliance on legal precedent, in other words, tends to exclude from consideration those economic criteria which must be considered if any sound decision is to be reached. The basic assumption of the lawyer is that a case is rightly decided if due regard to precedent is given within rules of his craft. The basic assumption of the economist is that a solution of any problem demands the investigation, weighing and analysis of all relevant data and criteria.

It must be acknowledged that there is a small group of antitrust specialists among advocates and a small group of judges to whom the foregoing strictures are inapplicable. They have risen to an impressive maturity in their sensitiveness to the intricate problems involved in the regulation of the business institution under our present system of antitrust laws. One of the basic problems of the law schools and the legal profession is to expand that area of competence. Perhaps the heart of the problem lies in the trial, for when judges can match counsel in their know-how of the field, sound results are usually achieved. But the courts have few Learned Hands and few Brandeis's. ${ }^{29}$

An analogous situation exists in the patent field. It is believed that any patent lawyer could give instances in which the most extraordinary, fanciful and flimsy theories were solemnly proffered to judges in an effort to invalidate patents. Such practices are an inevitable consequence of the hurly-burly tactics of the trial, of the litigious equation. It is for the judge to weigh and evaluate, not for trial counsel. Correspondingly in the $A \& P$ case $^{30}$ the economies resulting from integration were successfully contended by the prosecution to be "subsidies" whereby the non-integrated retailers were unlawfully driven from the market in price competition, a theory which essentially involves the fallacy of "begging the question" from the economist's point of view. In law, however, when the savings of integration were passed on to the consumer, a violation of the antitrust laws was held to have occurred. If the court is to make a choice between the interest of protecting competitors

29. An interesting recent development in this connection is the appointment of an economist, Carl Kaysen, to be law clerk to Federal Judge Wyzanski to assist in the United Shoe Machinery case now pending before him.

30. United States v. New York Great A.\&P. Tea Co., 67 F. Supp. 626 (E.D. Ill., 1946), aff'd, 173 F.2d 79 (7th Cir. 1949). 
from the rigors of aggressive price compeition and the interest of preserving the system of price competition itself, let it at least be a knowing choice.

A second conclusion which recent comment of the profession would support is that even when the basic economic problem is faced, subject to the limitations of legal technique just noted, the massiveness of the problem itself renders it impossible for the court to consider all relevant evidence proffered. The problem of the record, the problem of the trial of an antitrust case today, is so prodigious, that some winnowing and evaluating of evidence must be done by the parties or directed by the judge if the trial is not to become a lifetime career for the advocates and the judge. ${ }^{31}$ Judge Medina recently said in the trial of the Investment Bankers case, "Pretty soon I'm going to make some ruling to curtail the proof so we won't be here the rest of our lives."32 Thus the final conclusion reached by the court may be at best only an approximation of truth, though a skilled organization of the evidence would by itself considerably simplify the judicial task..$^{33}$

\section{The Antitrust Laws and the Definition of Norass of Conduct FOR THE BUSINESS INSTITUTION}

As with all legal problems, the problem of the antitrust laws involves both questions of policy and technique of control. In the preceding section it was seen that the formal, logical approach of the legal method often closed the door to inquiry into many of the relevant aspects of economic and public policy presented in the cases brought to the courts for decision. The point was further made that the legal technique itself was "ill-suited" to the sound handling of the complex economic issues and data involved in such cases. These criticisms should not be construed to imply that the courts have failed altogether or even considerably in their task. Given the limitations under which they work, it has certainly been the consensus that theirs has been a creditable performance and one that has served the public interest well in the past six decades.

The issues now confronting the courts, however, are so weighty, are so fraught with possible incalculable harm to our economic society, that we must now face the question whether we can continue to rely exclusively on the courts and our existing structure of antitrust laws to take care of the public

31. Dession, The Trial of Econonic and Technological Issues of Fact, 58 YALE L.J., 1019, 1242 (1949) ; McAllister, The Big Case: Procedural Problems in Antitrust Litigation, 64 HARv. L. REv. 27 (1950) ; McAllister, Stating the Issues, CCH FEDERAL ANTITRUST LAW SyMrosium, 13 (1951); Baldridge, Simplifying and Expediting Cases, id. at 23; Hand, Trial Efficiency, id. at 31; Handler, Anti-Trust-New Frontiers and New Perplexities The Record of the Assoctation of the Bar of the City of New York, 59, 81 (1951).

32. N.Y. Times, Mar. 17, 1951, p. 22, col. 4.

33. Consider Judge Prettyman's suggestions, including the card indexing of evidence, in Prettyman, Six Suggestions for Improvement, CCH FEDERAL ANTI-TrUST LAw SyMPosium 34 (1951). 
interest in the control of the functioning of the business institution. The implications of the $A \& P$ case upon integrated business enterprises generally, the implications of the Standard of California decision coupled with the recent amendment to Section 7 of the Clayton Act prohibiting corporate mergers, the current attack on the concept of bigness by the Antitrust Division, including the DuPont-General Motors ${ }^{34}$ complaint, are some of the highly important issues presented in current developments in the antitrust field. It is essential for our country's future that we proceed wisely and carefully and subject to no illusions or predetermined conclusions in antitrust issues of the gravity which these present. Not logic but experience must dictate their solution.

It will be observed that throughout this article the basic problem has been stated to be that of the control of the conduct of the business institution rather than a problem of preserving "competition." The hypothesis of pure competition as the perfect regulator of the economy was essentially an outgrowth of the naturalist, laissez-faire philosophy utilized at the close of the eighteenth century and the beginning of the nineteenth to establish the independence and power of the new mercantile interests and class as against the landed interests. Today the problem is one of establishing a rational system of control of the business institution, rather than the attainment of the blissful Nirvana of perfect competition. If economists are agreed upon anything today it is the inevitableness of imperfect competition in our economic life.

The reason for this emphasis upon the business institution as the focal point of our inquiry has in part been indicated in the remarks at the outset of this article on the emergence of the modern corporate institution as presenting a problem in the distribution of power. The issue of the possession of power by the corporate institution is the one central issue in the meaning of the terms "freedom" and "competition," the necessity of keeping the door open to alternatives of action by the individual, to an effective choice among the institutions in which he may participate. When that door is closed through slums and overcrowding, through lack of educational opportunity, or through denial of human rights, participation in criminal and anti-social activities results. For theirs is in such circumstances the only effective choice of the submerged individuals seeking to break out of their environment. When that door is open, however, the institution becomes the source of great productive energy, an energy derived through the forces of reward, loyalty, and cooperation rather than through arbitrary compulsion. Corporate management has today developed an extraordinary technique in maximizing the human energy of the participants in the corporate institution and the physical energy of its capital equipment. Means of communication within the group, progressive rewards for contributions to the group, internal norms of conduct and sanctions therefor, all of these must be effectively organized if the institution is to survive in the constantly rising plane of competition. For as the choice of

34. United States v. E.I. du Pont De Nemours \& Co., Civil No. 49C-1071, N.D. Ill, filed June 30, 1949. 
workers or the choice of customers to participate in the functioning of a particular business institution becomes less attractive as compared with the opportunities proffered by competing institutions, in that measure the institution lags in its growth or finally dies. When the door to freedom of choice is closed to the extent that it is in the Soviet system, and reliance on fear and force instead becomes the dominant means for achieving the ends of the social system, then the energy potential of the institutional life of the society is correspondingly sluggish. So long as a real choice among the institutions in which the individual shall participate is kept alive, then, on the one hand, the directing personnel of those institutions will be subject to the constraint of relying upon inducement to action rather than compulsion and, on the other hand, the members of the institutions will find that their lives have that freedom of action which is the essential characteristic of the democratic state. The business institution thus possesses a source of energy that the political institution, the state, can only very imperfectly and infrequently realize. The state is essentially a system of force. The state in the western democratic system does not primarily rely on fear and force and seeks to accommodate its structure of force to the accustomed habits and mores of its citizens. Nevertheless, only imperfectly and in times of great national emergency is it able to induce rather than compel action. The corporate institution, however, is one in which participation is voluntary. While man must work and man must buy in our society, if he is to live, his freedom to select and choose the institution in which he shall work and from whom he shall buy should be preserved. From that fact flows the energy of western civilization.

As we saw at the outset of this article the purposes of society and the purposes of the business institution are not necessarily identic. For it is the blind tendency of all institutions to expand and the directing force of the activity of the modern corporate institution is the profit motive. The manner of the expression of that motive varies from industry to industry and fluctuates with the fluctuations of the business cycle itself. A gadget manufacturer is infinitely more venturesome in risk taking than say a manufacturer of locomotives. A manufacturer will tend to integrate forward into the retail market in a deflationary economy and to integrate backward to assure continued sources of supply in an inflationary, expanding economy when consumer demand is ample. Consequently, behaviors of the business institution vary from industry to industry and from period to period. Behaviors of business institutions will also be determined to some extent by the psychology of their managers (compare the post-war history of Sewell Avery and Montgomery Ward with General Wood and Sears-Roebuck). Deviations of corporate behavior and structure brought about by factors such as these lead to the question: When shall the organized force of the political community be brought to bear to prevent or punish the behavior of the corporate institution?

Note that this is not the question which the economist considers in his investigations. There may be business conduct that is unsound economically 
or there may be corporate structures that are fantastic from the long-run economic point of view (as distinguished from the profit point of view of the entrepreneur himself). The question with which we are faced when we say "there ought to be a law" is a different and a narrower question. It is instead: When is the behavior under consideration sufficiently injurious to the interests of the community to justify the interposition of its organized procedure of force?

In order to answer that question we must first endeavor to determine our basic objectives. If we are seeking to preserve the free institutional activity that it is the central characteristic of the American economic system, we must insure that each economic institution is (i) afforded access to supplies subject to no restraint imposed by any other economic institution, (ii) enabled to enter such markets and select such type of internal organization as it may determine, again subject to no restraints directly imposed by other economic institutions, so as to provide means of experimental growth of each such institution and a stimulus to the dynamic expression of its fundamental purpose or purposes in our economic life, and (iii) afforded access to the market for its product subject to no restraint on the part of other economic institutions. The foregoing analysis is supported by current economic thought which is tending to place more emphasis on the performance of the economic institution and less upon the mechanical aspects of market structure, i.e., the size, both relative and absolute, of the various institutions comprising the industry in question. ${ }^{35}$ For the rivalry of competition is but an assumed condition of satisfactoriness of performance. Sometimes, as in the case of public utilities, satisfactory performance must be sought by means other than the competitive struggle. Performance and structure are complementary instead of self-exclusive criteria. The current emphasis on performance must be viewed as an attempt to add to the relevant criteria for investigation rather than to subtract.

To some extent the above objectives have already been translated by the courts into rules of illegality per se. Competitors may not be purposefully excluded from sources of supply. ${ }^{36}$ The lawful monopoly of a patent may not be used to coerce the buyers of products outside the scope of the patent. ${ }^{37}$ Whether there be a combination of sellers ${ }^{38}$ or a seller possessing monopoly power, ${ }^{30}$ buyers are to be afforded access to a competitive market.

35. Clark, Toward a Concept of Workable Competition, 30 Am. Econ. Rev. 241 (1940); Adelman, Effective Competition and the Anti-Trust Laws, 61 Harv. L. Rev. 1289 (1948); Mason, The Current Status of the Monopoly Problem in the United States, 62 Harv. L. Rev. 1265 (1949); Nourse, Price Making In a Demrocracy (1944); but cf. Enwards, Mraintaining Competition (1949).

36. Associated Press v. United States, 326 U.S. 1 (1945).

37. International Salt Co. v. United States, 332 U.S. 392 (1947); Note, Patent Abuses and Antitrust: The Per Se Rule, 64 Harv. L. Rev. 626 (1951).

38. United States v. Socony-Vacuum Oil Co., 310 U.S. 150 (1940).

39. American Tobacco Co. v. United States, 328 U.S. 781 (1946). 
The courts have been less successful in dealing with the second objective listed above. The problem of vertical integration has recently been viewed from the utterly fanciful basis of "subsidy" in the $A \& P$ case, or from the inconsequential and irrelevant standpoint of the exclusion of competing suppliers in the Yellow Cab and Standard of California cases. In only the Columbia Steel case does the court approach the problem on the basis of a relatively complete analysis of the economic consequences of the integration in the relevant markets. If the second objective is a sound one, it suggests that the public interest in flexible, dynamic corporate activity is not served when the problem of integration is viewed solely from the point of view that competing sellers are thereby precluded from a not insubstantial segment of the market represented by the acquired concern. The application of such a rule would automatically condemn almost all vertical integrations, and, though the court denied in the Columbia Steel case that such was its intention, the Standard of California case throws new doubt upon the question. The test should be: Does the integrated institution at any point where its products reach the market exert such a dominant or monopolistic force in the market as to deprive buyers of the opportunity of effective choice? It was essentially this test that was applied by the court in the Columbia Steel case and this test was the real significance of Judge Hand's decision in the Alcoa case, in which the defendants' monopolistic position in the stage of ingot production of primary aluminum was made the basis for the finding of monopoly power. ${ }^{40}$ The same test was formerly applied by the courts in the tying-clause cases under Section 3 of the Clayton Act, ${ }^{41}$ in which market dominance was made the turning point as to whether such conduct substantially restrained competition. A more realistic approach would have been to condemn the dominance itself, ${ }^{42}$ rather than the abuse which the possession of such power made possible.

The same test may also furnish a workable approach to the problem of size itself or of horizontal integration. Here too the issues for the antitrust lawyer are not necessarily the same as those which concern the economist, though the analysis of the economist throws light upon the problems of the lawyer. For example, the economist seeks an answer to the question whether the limitation of all business institutions to a size measured by the factors of technological efficiency alone (e.g., a steel plant) would adequately take care of the social need of research and technological advance and the development of skills and know-how growing out of a business occupying diversified fields (e.g., the Du Pont system of enterprise). The lawyer should be concerned only with such questions as whether the ownership connections in the Du Pont system exert undue dominance in any of the markets it occupies. It should be realized

40. United States v. Aluminum Co. of America, 148 F.2d 416 (2d Cir. 1945).

41. Standard Fashion Co. v. Magrane-Houston Co., 258 U.S. 346 (1922) ; cf. B. S. Pearsall Butter Co. v. FTC, 292 Fed. 720 (7th Cir. 1923).

42. Aluminum Co. of America v. FTC, 284 Fed. 401 (3d Cir. 1922); cf. United States v. Republic Steel Corp., 11 F. Supp. 117 (N.D. Ohio, 1935) both under Section 7 of Clayton Act). 
in this connection that undue dominance does not necessarily flow from size alone; market control may be achieved by other and indirect means. Dominance in the supply of titanium may achieve indirectly a dominance in the paint industry employing titanium compounds. The problem of undue dominance in turn breaks down into a number of most difficult issues of fact. What is the "commodity" which shall be taken for purposes of investigation ?43 Is it to be distinguished by its composition, as in the case of rugs made from linen, ${ }^{44}$ or by the fact that it is a rug, or by its end purpose as a floor covering, which would enable it to be classed with such commodities as linoleum? Lastly, when does dominance become undue, that is, raise questions of public policy of a sufficient gravity to justify the interposition of legal controls? The answers to questions such as these cannot be given by the lawyer alone or by the economist alone. In their solution, the lawyer must at times assume the leading role and at other times the economist. There need be no separation of their work, their functions are complementary.

A beginning effort to consider questions such as these was recently made by the President's Committee on Business and Government Relations headed by Secretary of Commerce Sawyer. Some interesting suggestions as to fields for inquiry have been made to this committee, ${ }^{45}$ but no report by it has as yet been made. The hearings of the Celler Committee have been productive of much useful information, though the approach of the committee has not always been one of dispassionate scientific curiosity. It may be that the "commission" approach to the problem of the revision of the antitrust laws, such as the Royal Commission Reports in England or the Wickersham Report on the problem of crime in this country would be helpful.

Institutionalized research by lawyers and economists, among others, is essential if we are to arrive at any norms for conduct beyond those that the courts have given us up to this point and if we are properly and soundly to evaluate such norms. It would seem that the economist should assume a much larger responsibility in this task than he has in the past; his advice up to this point has tended to be both inadequate and conflicting. ${ }^{46}$

In the definition of these norms a clear distinction must be made beween those that are to be made subject to criminal penalties and those that are to be subject to civil procedure, if we are to have an effective observance as well as

43. "A monopoly is simply a product under a single control and significantly different from others on the infinite chain of substitutes." Chamberlin, Product Heterogeneity and Public Policy, 40 Proc. Am. Econ. Assn. 85, 86 (1950).

44. United States v. Klearflax Linen Looms, Inc., 63 F. Supp. 32 (Minn., 1945).

45. E.g., Letter of Transmittal and Memorandum for the President's Committee on Business and Government Relations Submitted by a Special Committee of the Section on Anti-Trust Law of the New York State Bar Association, dated July 10, 1950.

46. Note the conflicting testimony of economists in the Cement Institute case supra note 28 , reminiscent of the conflicting testimony of expert witnesses in patent infringement suits. 
enforcement of the antitrust laws. Under the original conception of the Sherman Act in clear categories of black and white instead of the infinite shadings of fact involved in present-day judicial doctrine, it was a matter of indifference whether civil or criminal penalties were imposed. ${ }^{47}$ Now, however, there is almost no field of law as esoteric, replete with conflicting authorities and lines of authority, posing as difficult problems of public policy and as complex fact situations as antitrust law. In these circumstances is it consistent with the rule of mulla poena sine lege ("no punishment without law") to subject those charged with the management of business to the risk of criminal punishment for decisions responsive to the stimuli of the market? ? $^{43}$ In the making of management decisions an exraordinary amount of market, cost and other data are examined and weighed. Counsel are consulted and the current status of antitrust decisions considered. Past decisions are reevaluated in the light of new trends in the law. ${ }^{49}$ Yet such decisions always raise questions of public control and, when these questions are of sufficient public interest, they demand examination by the courts. It is always possible that a criminal prosecution may be invoked for the purpose of such examination, with the consequent trial taking place under expanded concepts of conspiracy which so far the criminal courts themselves have shrunk from applying in the historical categories of crime. In the Tobacco case ${ }^{50}$ counsel for Liggett \& Myers argued that "the common practices of the tobacco industry are in many instances usual features of business life today, and in all instances practices which businessmen guided by ... self interest, acting reasonably and in the absence of agreement, might adopt."51 Counsel for Reynolds pointed out:

"... [T] he significance of these convictions extends far beyond the immediate consequences to petitioners and the tobacco industry.... For, if these convictions be lawful, the pattern of prosecution is applicable-with the result of almost certain and repeated conviction-to every other executive and corporation in a mass production industry. ... in which, as a matter of common knowledge, economic forces have produced identities or close similarities in manufacturing, packaging, pricing, advertising, marketing and even raw material acquisition."62

We desire a workable antitrust law as well as workable competition. That law should be formulated so as to foster and not to inhibit dynamic enterprise, risk-taking and imaginative business decisions. Vigorous business policy

47. See remarks of Senator Sherman, 21 Cong. REc. 2456-7, 2459-60 (1890).

48. Nash v. United States, 229 U.S. 373 (1913) (sustains the constitutionality of the Sherman Act in the light of the rule of reason of the Standard Oil case).

49. Van Cise, Practical Planing, CCH Federax Antritrust Law Symposiuni 103 (1951).

50. American Tobacco Co. v. United States, 328 U.S. 781 (1946).

51. Brief for Appellants, p. 234, Liggett \& Myers v. United States, 147 F.2d 93 (6th Cir. 1944).

52. Petition for Writ of Certiorari, p. 14, Reynolds v. United States, No. 840, U. S. Supreme Court, Oct. Term, 1944. 
should not be constantly subject to the inhibitory threat of criminal prosecutions; instead, only those acts or business decisions which can clearly be said in advance to entail public injury should be made criminal. For the business leader's loyalty is to his enterprise and when doubt exists his decision will ever tend to be cast on the side of advancing the interests of his institution. A modification of our twofold legal system of civil and criminal controls is accordingly needed, the system of civil remedies, i.e., injunctive relief, should be applied to novel cases raising questions whether new forms of business behavior must be controlled, and the criminal procedure should be limited to cases involving reasonably objective categories of conduct. With such a distinction established, courts would be much freer to develop the law in the civil cases, knowing that their decisions would not have unfair or undesirable implications from the standpoint of the system of criminal law, more dynamic business behavior would be fostered, and it would be possible in all justice to make more severe the penalties of the criminal law as deterrents to violations of the antitrust laws.53 In short, it is proposed that injunctive relief be available for any violation of the Sherman Act as now provided, that actions for damages be available to any person injured by violations of the Sherman Act, that the prohibitions of the Act remain unchanged so as not in any manner to disrupt its jurisprudence, but that criminal penalties and actions for treble damages, which are also punitive in nature, be limited to specified categories of conduct.

The heart of the task which lies before us lies in the fact that the law tends to concern itself with the abuse of power rather than the problem of power itself. Criminals are punished by reason of their overt conduct and not because of their predisposition to crime. Yet if the corporate institution be conceived of not as an entity or personality but as a system of relationships, then the problem of power itself can be handled by the law and the law can expand beyond the domain of abuse of power to which it hitherto has been principally confined. ${ }^{54}$ If the approach herein suggested be adopted, the law can then grapple directly with the problem of power itself. The basic difficulty is to formulate an approach that will be sound from the standpoint both of judicial administration and of economics. If the approach be free from static concepts, from concepts of an absolute or mechanistic nature, and the problem of power be viewed instead as a problem in relative power, then the way will be open for a new approach to the application of the antitrust laws.

The time is indeed at hand for the lawyer, the economist, the legislator, and the expert in jurisprudence to pool their respective skills and knowledge in a new formulation of our antitrust laws. The revision of these laws should be removed from politics and placed in the field of policy and statecraft.

53. See the Walter Bill, H.R. 2401, 82d Cong., 1st Sess. (1951), increasing the maximum fine for criminal violation of the Sherman Act from $\$ 5,000$ to $\$ 50,000$.

54. Supra note 2. Cf. Rostow, Monopoly under the Sherman Act: Power or Purpose?, 43 ILI. L. REv. 745, 763 (1948); Comment, Vertical Integration in Aluminum: $A$ Bar to "Effective Competition", 60 YALE L.J. 294, 296 n.16 (1951). 